\title{
BIOTECHNOLOGICAL PROCESSES IN THE TECHNOLOGY OF FORMING OF LEATHER MATERIALS
}

\author{
A. Danylkovych, V. Lishchuk, O. Okhmat \\ Kyiv National University of Technologies and Design
}

\begin{tabular}{l}
\multicolumn{1}{c}{ Key words: } \\
Biotechnological \\
processes \\
Soaking-unhairing of \\
leather raw materials \\
Formation of leather \\
materials \\
Production of elastic \\
leather \\
\hline \multicolumn{1}{c}{ Article history: } \\
Received 06.09.2018 \\
Received in revised form \\
27.09.2018 \\
Accepted 11.10 .2018 \\
\hline
\end{tabular}

Corresponding author:
A. Danylkovych
E-mail:
npnuht@ukr.net

\begin{abstract}
Biocatalytic processes are investigated in the paper in order to increase the elasticity of the leather materials by received unhairing and liming semi-finished product that is exposed to proteolytic treatment by enzymes. The aim of this work is to investigate the influence of probiotic bacteria Bacillus subtilis, enzymes of pancreatin and Chemizym BH ("Chemipol" company, Poland) on the effectiveness of soaking, unhairing, liming and softening processes in leather production technology. The effectiveness of biochemical reagents in technological solutions and the duration of leather raw materials processing were determined.

Rabbit leather processed by a fresh-dry method of canning in the thickness of $1.2-4.1 \mathrm{~mm}$ at the unhairingliming phase and cattle - a bull-calf processed by a saltywet method of canning after unhairing-liming and doubling to a thickness of $2.0-2.2 \mathrm{~mm}$ were used. The effectiveness of biochemical reagents was determined by evaluation of the chemical composition and physical-mechanical properties of the formed leather semifinished product.

The reduction of duration in the soaking leather raw materials in the technological process was set to double and the $20 \%$ reduction of environmentally harmful reagents while liming was established. The developed biotechnology of soaking-liming of leather raw materials makes it possible to combine the implementation of successive processes of leather raw materials alkaline processing into one-stage technological cycle.

For the production of chrome-tanning elastic leather shoe, including working and military footwear, clothing and haberdashery, it may be considered the expediency to carry out unhairing-liming processes using the enzyme preparation of Chemizym BH at a concentration of $0.3 \%$ and $100 \%$ water consumption of the half-finished liming product weight during 12 hours with the next one-hour softening.
\end{abstract}

DOI: $10.24263 / 2225-2924-2018-24-5-4$ 


\title{
БІОТЕХНОЛОГІЧНІ ПРОЦЕСИ В ТЕХНОЛОГІЇ ФОРМУВАННЯ ШКІРЯНИХ МАТЕРІАЛІВ
}

\author{
А.Г. Данилкович, В.І. Лішук, О.А. Охмат
}

Київський наиіональний університет технологій та дизайну

У статті досліджено біокаталітичні прочеси відмочування-зоління шкіряної сировини в технології виготовлення еластичних шкір. Мета дослідження полягала в тому, щоб довести ефективність використання бактерій Ваcillus subtilis і ензимів панкреатину та CheтіzутВН (фірма «Cheтipol», Польща) y підготовчих прочесах формування шкіряних матеріалів.

Для дослідження використано шкури кроля прісно-сухого методу консервування товщиною 1,2-1,4 мм на стадї̈ зневолошування-зоління та сировину великої рогатої худоби - бичка мокросоленого методу консервування після зневолошування-зоління і двоїння на товщину 2,0-2,2 мм. Ефективність біохімічних реагентів визначено иляхом оцінювання хімічного складу $i$ фізико-механічних властивостей сформованого шкіряного напівфабрикату.

У результаті дослідження встановлено скорочення тривалості технологічного процесу відмочування шкіряної сировини вдвічі та зменшення на $20 \%$ витрат екологічно небезпечних реагентів при золінні. Розроблена біотехнологія відмочування-зоління шкіряної сировини дає можливість об'єднати виконання послідовних процесів лужного оброблення шкіряної сировини.

Реалізачію технологій зневолошування-зоління з використанням ферментного препарату Cheтіzут ВН за конщентраиіï 0,3\% та витраті води 100\% маси золеного напівфабрикату впродовж 12 год з подальшим одногодинним м'якшенням у виробничих умовах можна вважсати перспективною для виробництва еластичних шкір хромового дублення - взуттєвих, у тому числі для робочого і військового взуття, одягових і галантерейних.

Ключові слова: біотехнологічні прочеси, відмочування-зневолошування шкіряної сировини, формування шкіряних матеріалів, виробниџтво еластичних шкір, фізико-хімічні властивості.

Постановка проблеми. Технології формування шкіряних матеріалів характеризуються багатостадійністю, складністю їх виконання і техногенністю на окремих стадіях. Особливо це проявляється на стадії отримання зневолошеного шкіряного напівфабрикату, коли консервована колагенвмісна сировина піддається відновленню структури під дією водних розчинів лужних реагентів за наявності ензимів класу гідролаз [1] 3 подальшим руйнуванням зв'язків м'яких кератинів епідермісу і волосяних сумок, які розташовані в сосочковому шарі дерми, під дією сульфідно-вапняного розчину. Ефективність ензимних препаратів цього типу обумовлена їх прискореною каталітичною дією щодо реакції розщеплення зв'язків - амідних, естерних, пептидних, у яких карбоксильні групи належать основним амінокислотам лізину й аргініну колагену. При цьому структура дерми шкур тварин звільняється не тільки від консервуючих реагентів, але й від глобулярних білків, частково від мукополі- 
сахаридів і ліпідів. У подальшому напівфабрикат з підвищеним вмістом вологи завдяки зв'язаним 3 колагеном іонам кальцію обробляється надлишковою кількістю сульфату амонію при знезолюванні напівфабрикату з утворенням подвійної солі сульфату кальцію, що має підвищену розчинність у воді.

Аналіз останніх досліджень і публікацій. Ензимні препарати широко застосовуються у різних технологічних обробленнях [2]. Відоме використання ензимних препаратів у відмочувально-зольних процесах технологій виробництва еластичних шкіряних матеріалів [3], зокрема для процесу зневолошування використано ензимний препарат протосубтилін Г10х [4], тоді як процес знезолювання може бути здійснений за допомогою ензимів LITHUDAC L i Novo Bate WB, які активні в кислому середовищі [5]. Для знежирювання та підвищення ефективності цих процесів можуть бути використані лужні ліпази або комбінація лужних протеаз і ліпази [6]. Протеолітичні ензими і трипсин рекомендується використовувати для деструкції вторинних ресурсів, що утворюються у виробництві хромових шкір. Технологія оброблення шкур прісно-сухого методу консервування на стадії відмочування передбачає застосування ензимних препаратів, таких як мальтаваморин Г10x, пектофоетидін П10х, амілосубтилін ГЗх [7], що дає змогу не тільки скоротити тривалість циклу відмочування технологічного процесу, але й знизити дефектність шкурок при їх механічних обробленнях завдяки підвищенню пластичності шкірної тканини. Слід зауважити, що використання препаратів високого ступеня очищення (як 10x) недоцільно практично застосовувати у хутровому і шкіряному виробництвах, хоча це дає можливість прецезійно рогулювати технологічний процес.

Використання ензимних препаратів протосубтиліну Гзх, пектофоетидіну П10x, мальтаваморину Г10x для відмочування [8] та пектоаваморину П10x i пектофоетидіну П10х разом з ПАР для оброблення овчин з ущільненою шкірною тканиною значних розмірів понад 90 кв. дм прискорює видалення ліпідів та забруднень білкової і вуглеводної природи з волосяного покриву й шкірної тканини. При цьому ПАР забезпечує диспергуючий ефект щодо продуктів біодеструкції неколагенових складових дерми під час механічних впливів на сировину. Такі препарати протеазної і глікозидазної дії можна використовувати для отримання поліфункціональних шкіряних матеріалів 3 сировини 3 підвищеним вмістом жирових речовин. При ензимному обробленні ці препарати забезпечують руйнування мембран жирових клітин i емульгування їх вмісту. При цьому активність ензимів суттєво залежить від $\mathrm{pH}$ середовища. Зокрема, ліпаваморин ГЗх проявляє ліполітичну активність в інтервалі $\mathrm{pH} 5,5-8$, протосубтилін ГЗх має максимальну протеолітичну активність за $\mathrm{pH} 7,5-8$ і зберігає 80\% активності в інтервалі $\mathrm{pH} 6,5-9$, а препарат протосубтилін Г10х проявляе максимум протеолітичної активності за вищих значень середовища робочих розчинів, але 3 підвищенням лужності до $\mathrm{pH} 12,5$ його активність знижується на $60-70 \%$. Слід відзначити, що ензимний препарат Tannerzyme зберігає понад $90 \%$ протеолітичної активності в інтервалі $\mathrm{pH} 9-12$ і може бути використаний при зневолошуванні-золінні шкіряної сировини. 
Оптимум активності ензимних препаратів суттєво залежить від температура робочих розчинів. Зокрема, оптимальна протеолітична активність протосубтиліну ГЗх проявляється за температури $40-50^{\circ} \mathrm{C}$, а за 30 та $65^{\circ} \mathrm{C}$ його хімічна активність знижується вдвічі. Тоді як оптимальна дія ліпаваморину ГЗх проявляється за температур $35-37^{\circ} \mathrm{C}$ i, відповідно, за 20 і $55^{\circ} \mathrm{C}$ його активність знижується на $30 \%$ і повністю інактивується. Температурний оптимум для протомезентерину ГЗх досягається за $60-65^{\circ} \mathrm{C}$, а $3 \mathrm{a} 35-37^{\circ} \mathrm{C}$ його активність знижується на $44 \%$.

Біотехнологічна активність ензимних препаратів також суттєво залежить від наявності у робочому розчині супутніх реагентів - хлориду і сульфіду натрію, гідроксиду кальцію, сульфату амонію тощо. 3 підвищенням або зниженням їх вмісту протеолітична активність ензимних препаратів змінюється. Так, встановлено зниження протеолітичної активності протосубтиліну Г10х [3] за наявності хлориду натрію або сульфату амонію на $10-15 \%$, гідроксиду кальцію - на 5\%, а карбонат натрію позитивно впливає на протеолітичну активність лужних протеїназамінів. Активність ензимного препарату актиноміцету III, який має два максимуми протеолітичної активності, за наявності хлориду амонію чи хлориду натрію, сульфату, сульфіту або гідросульфіту натрію знижується в середньому на $10-15 \%$. Слід відзначити, що ензимні препарати не можуть використовуватись при сульфідно-вапняному обробленні шкіряної сировини, оскільки за наявності сульфіду натрію майже повністю втрачається протеолітична активність досліджених ензимів.

Проведений аналіз літературних джерел свідчить про використання в технологіях виробництва шкір широкого асортименту біохімічних препаратів, активність яких суттєво залежить як від умов технологічного процесу, так і від хімічного складу супутніх реагентів. Для зниження собівартості шкіряних матеріалів доцільно використання на стадіях зневолошування і м'якшення бактеріальних препаратів, які самі продукують ензими різного типу, антибіотики та інсектициди, що мають здатність існувати за умов відсутності кисню і живлять органічні та неорганічні сполуки тощо. Диференціація виділення ензимів $є$ досить трудомістким і високовартісним процесом. Також для очищення стічних вод шкіряного виробництва хромових шкір використовуються бактеріальні препарати.

Тож комплексне використання розширеного асортименту бактеріальних препаратів та ензимів у технологічних процесах виготовлення еластичних шкіряних матеріалів можна вважати актуальним. Враховуючи високу деструктивну активність препаратів [2], їх використання вимагає оптимального i ретельного контролю технологічних параметрів при відповідних обробленнях.

Мета статті: дослідження впливу бактерій Bacillus subtilis і ензимів панкреатину та Chemizym BH (фірма «Chemipol», Польща) на ефективність проведення процесів відмочування, зневолошування, зоління й м'якшення в технології виробництва шкіряного матеріалу.

Викладення основних результатів дослідження. Для підвищення еластичності шкіряних матеріалів отриманий зневолошений і знезолений напів- 
фабрикат піддається протеолітичній дії ензимами в процесі м'якшення. При цьому відбувається подальше видалення мукополісахаридів з поверхні волокнистих структурних елементів дерми. Для ефективного проведення цих процесів необхідно оптимізувати режим ензимного оброблення з метою усунення деструкції колагену дерми. При виборі ензимних препаратів для прискорення фізико-хімічних процесів відмочування, знежирювання, зневолошування, м'якшення суттєве значення мають умови консервування сировини і цільове іiї використання. Про високу деструктивну властивість аеробних бактерій свідчить їх широке застосування у різних технологічних розробках [2].

У дослідженні використані шкури кроля прісно-сухого методу консервування товщиною 1,2-1,4 мм на стадії зневолошування-зоління та великої рогатої худоби - бичка мокросоленого методу консервування після зневолошування-зоління і двоїння на товщину 2,0-2,2 мм. Як біохімічні реагенти застосовано бактерії Bacillus subtilis, синтезовані на м'ясному бульйоні в Інституті колоїдної хімії і хімії води імені А.В. Думанського НАН України, препарат панкреатин, який містить ряд протеолітичних ензимів [3] — протеіназ і пептидаз, основним з яких є протеіназа трипсин, а також ліпазу, амілазу й еластазу. Крім того, використано ензимний препарат Chemizym BH 3 активністю 10 од./мг за температури $32-37^{\circ} \mathrm{C}$ i $\mathrm{pH}$ середовища $7,8-8,5$.

Ефективність біохімічних реагентів визначали шляхом оцінювання хімічного складу і фізико-механічних властивостей сформованого шкіряного напівфабрикату. Зокрема, ефективність дії ферментного препарату панкреатину визначали за кількістю витопленого желатину із знезоленої та знезоленоїм'якшеної голини (зневолошений напівфабрикат з підвищеним вмістом вологи) [3]. Попереднє підготовлення зразків напівфабрикату для сорбційнодифузійних досліджень щодо води проводилась їх спиртово-ефірним зневоднюванням. Для дифузійних і фізико-механічних досліджень зразки були стандартизовані за нормальних умов. Фізико-механічні показники напівфабрикату визначали на розривній машині РТ-250М при швидкості деформування зразків $90 \mathrm{Mм} /$ хв.

Для отримання еластичних шкіряних матеріалів зневолошений і знезолений напівфабрикат підлягає протеолітичній дії ензимів у процесі м'якшення. На основі попередніх експериментів встановлено доцільність заміни в технологічних розчинах процесу відмочування шкіряної сировини хлориду натрію на сульфіт натрію сумісно з препаратом Bacillus subtilis. Про ефективність дії бактерій Bacillus subtilis свідчить підвищення ступеня обводнення і використання сполук хрому (III) порівняно 3 контрольним варіантом, відповідно, на 3,6 і 33,8\% (табл. 1, 2).

Відмочування шкурок кроля (табл. 1) проводили в лабораторних умовах за трьома варіантами в межах температури $36-38^{\circ} \mathrm{C} \mathrm{i} \mathrm{pH}$ робочого розчину 6,7-7,0 при витраті препарату Bacillus subtilis 15 мл/л технологічного розчину, який взято у співвідношенні до маси сировини 4:1 (рідинний коефіцієнт дорівнює чотирьом). Тривалість процесу відмочування визначалась за ступенем поглинання технологічного розчину шкірною тканиною, який мав бути не меншим, ніж у зразка, обводненого за контрольною технологією (варіант 3). 
Таблиия 1. Відмочування шкурок кроля

\begin{tabular}{|c|c|c|c|c|c|}
\hline Варіант & Реагент, г/л & $\begin{array}{c}\text { Тривалість, } \\
\text { годин }\end{array}$ & $\begin{array}{c}\text { Ступінь } \\
\text { обводнення, } \\
\% \\
\text { \% }\end{array}$ & $\begin{array}{l}\text { Міздріння } \\
\text { після }\end{array}$ & $\begin{array}{c}\text { М'як- } \\
\text { шення, } \\
\text { годин }\end{array}$ \\
\hline 1 & $\begin{array}{c}\mathrm{Na}_{2} \mathrm{SO}_{3}-8 \\
\text { ПАР }-1\end{array}$ & $12-13$ & 65,8 & зоління & $1,0-1,5$ \\
\hline 2 & $\begin{array}{c}\mathrm{Na}_{2} \mathrm{SO}_{3}-8 \\
\Pi A P-1\end{array}$ & 24 & 68,5 & зоління & $0,9-1,0$ \\
\hline 3 & $\begin{array}{c}\mathrm{NaCl}-10 \\
П \mathrm{AP}-1 \\
\end{array}$ & $24-26$ & 64,9 & $\begin{array}{c}\text { відмочу- } \\
\text { вання }\end{array}$ & $1,0-1,5$ \\
\hline
\end{tabular}

Зневолошування шкурок кроля (крім другого варіанта) проводили намазним способом. У другому варіанті волос видалявся механічним способом після додаткового відмочування шкурок протягом 28 годин за наявності препарату Bacillus subtilis. Наступне зоління отриманого зневолошеного напівфабрикату всіх варіантів виконували у сульфідно-вапняному розчині при $\mathrm{PK}=1$. За контрольною обробкою витрати гідросульфіду і сульфіду натрію відповідно становлять 0,3 і 0,6\%, а гідроксиду кальцію - 1,2\% маси зневолошеного напівфабрикату. При цьому витрати хімічних реагентів у першому і другому варіантах зменшено на 20\% порівняно 3 контрольним. Підшкірна клітковина видалялась при міздрінні дослідних зразків після зоління, а у контрольних — перед зневолошуванням. Наступні технологічні процеси отриманого напівфабрикату виконували за промисловою технологією.

У технологіях перероблення консервованих шкур тварин процес обводнення пов'язаний з наближенням ступеня гідрофільності дерми шкур до стану «свіжої» шкури. Це обумовлено необхідністю збільшення міжмакромолекулярних проміжків для ефективної дифузії хімічних реагентів в об'єм дерми до центрів взаємодії. Тривалість процесу обводнення за першим варіантом була вдвічі меншою, тоді як при однаковій тривалості ступінь обводнення для другого варіанта підвищується. Скорочення тривалості процесу відмочування зумовлене активною дією бактерій Bacillus subtilis при однаковому хімічному складі технологічних розчинів першого i другого варіантів оброблення сировини.

Процес зневолошування у першому варіанті й контрольному здійснюється 3 використанням сульфідно-вапняної намазної суміші за температури 36 $38^{\circ} \mathrm{C}$, а у другому варіанті - завдяки дії екологічно безпечного бактеріального препарату. При цьому м’якшений напівфабрикат у всіх варіантах оброблення мав шовковисту поверхню на дотик. Однак тривалість процесу м'якшення напівфабрикату другого варіанта була зменшена на 33\%.

За даними хімічного аналізу (табл. 2), вміст сполук хрому в шкіряному напівфабрикаті першого і другого варіантів несуттєво відрізняється від контрольного, однак концентрація оксиду хрому (III) у відпрацьованому розчині другого варіанта була суттєво меншою. Слід відмітити, що гідротермічна стійкість напівфабрикату цього варіанта досягала максимального значення. Це можна пояснити більш ефективним проходженням процесу дефібрилізації 
колагену дерми у відмочувально-зольних процесах під дією бактерій Bacillus subtilis ще на стадії зневолошування.

Таблиця 2. Фізико-хімічні властивості структурованого напівфабрикату дослідних технологій

\begin{tabular}{|c|c|c|c|}
\hline \multirow{2}{*}{ Показник } & \multicolumn{3}{|c|}{ Варіант } \\
\hline & 1 & 2 & 3 \\
\hline Вміст у напівфабрикаті, \% в перерахунку на абсолютно & & & \\
\hline суху речовину: оксиду хрому (III) & 3,3 & 3,7 & 3,4 \\
\hline речовин, що екстрагуються органічними розчинниками & 7,1 & 6,9 & 6,2 \\
\hline білкової речовини & 86,4 & 87,2 & 87,5 \\
\hline Концентрація $\mathrm{Cr}_{2} \mathrm{O}_{3}$ у відпрацьованому розчині, г/л & 1,47 & 1,31 & 1,98 \\
\hline Гідротермічна стійкість, ${ }^{\circ} \mathrm{C}$ & 101 & 104 & 101 \\
\hline Уявна питома маса, г/см & 0,61 & 0,59 & 0,71 \\
\hline Об’ємний вихід, см³/100 г білкової речовини & 185,4 & 190,0 & 157,4 \\
\hline Межа міцності при розриві, МПа & 14,0 & 14,5 & 13,0 \\
\hline Видовження при напруженні 10 МПа, \% & 32,0 & 33,0 & 29,0 \\
\hline Видовження при розриві, \% & 50,0 & 53,0 & 47,0 \\
\hline Межа міцності лицьового шару, МПа & 11,6 & 12,3 & 10,0 \\
\hline
\end{tabular}

Гідротермічна стійкість напівфабрикату, одержаного за різними технологіями, змінюються симбатно вмісту оксиду хрому (III). При цьому структура дерми, що має значну пористість, є максимально сформованою порівняно 3 іншими варіантами оброблення. Аналогічним чином змінюється і об'ємний вихід шкіряного напівфабрикату, який досягає максимального значення для зразків другого варіанта.

Відповідно до ступеня структурування і стабілізації колагену дерми спостерігається зміна як межі міцності шкіряного напівфабрикату та його лицьового шару, так і деформаційних властивостей, отриманого за дослідженими варіантами. При цьому найбільш високі значення міцностно-деформаційних показників має структурований напівфабрикат, одержаний за технологією другого варіанта. Особливо це стосується міцності лицьового шару, що свідчить про найбільшу рівномірність і рівноважність проходження процесу дублення, структурно підготовленого ефективним проведенням попередніх технологічних процесів дерми шкурок кроля завдяки дії бактерій Bacillus subtilis.

Детальне дослідження процесу м'якшення шкіряного напівфабрикату 3 сировини великої рогатої худоби - бичка, проводили з використанням ензимного препарату панкреатину після зоління і знезолювання. Як свідчать одержані результати кінетичного дослідження, збільшення тривалості зоління 35 до 12 діб супроводжується зростанням кількості витопленого желатину зі знезоленого напівфабрикату в 2,8 i 3,4 раза, відповідно, для огузка і поли (табл. 3). Цей ефект підсилюється при підвищенні концентрації панкреатину з 0,6 до 2,2 г/л. При цьому кількість витопленого желатину збільшується на 18,7 i $27,4 \%$, відповідно, для огузка і поли. Це свідчить про руйнування не тільки міжмолекулярних зв'язків у структурі колагену дерми, але й часткову деструкцію його поліпептидних ланцюгів. 
Таблиия 3. Кінетика витоплення желатину з різних топографічних ділянок м'якшеного напівфабрикату

\begin{tabular}{|c|c|c|c|c|c|}
\hline \multirow{3}{*}{$\begin{array}{c}\text { Ділянка } \\
\text { напівфабрикату }\end{array}$} & \multirow{3}{*}{$\begin{array}{l}\text { Тривалість } \\
\text { зоління, діб }\end{array}$} & \multicolumn{4}{|c|}{$\begin{array}{c}\text { Витоплення желатину, } \\
\text { \% маси сухого залишку напівфабрикату }\end{array}$} \\
\hline & & \multirow{2}{*}{ знезоленого } & \multicolumn{3}{|c|}{ м'якшеного, годин } \\
\hline & & & 1 & 2 & 3 \\
\hline \multirow{4}{*}{ Огузок } & 5 & 30 & $\underline{8,7}$ & $\underline{7,1}$ & $\underline{5,7}$ \\
\hline & & & 14,9 & 14,5 & 14,2 \\
\hline & 12 & 8.3 & 12,4 & 12,7 & $\underline{12,4}$ \\
\hline & & & 27,4 & 28,4 & 28,8 \\
\hline \multirow{4}{*}{ Пола } & & & $\underline{12,1}$ & $\underline{11,7}$ & $\underline{11,4}$ \\
\hline & J & & 23,8 & $\overline{23,1}$ & $\overline{18,7}$ \\
\hline & 12 & 13.5 & $\underline{34,0}$ & 29,9 & $\underline{29,8}$ \\
\hline & 12 & 13,3 & 41,2 & 37,5 & 36,7 \\
\hline
\end{tabular}

Примітка. Витрата панкреатину при м'якшенні в чисельнику і знаменнику, відповідно, 0,6 і 2,2 г/л.

При суттєвому зменшенні концентрації ферментного препарату панкреатину в технологічному розчині за його витрати $0,05 \%$ маси золеної голини й відповідному зниженні активності та концентрації в робочому розчині (табл. 4) виявляється недостатній ступінь м'якшення при співвідношенні маси напівфабрикату до технологічного розчину як 1:3, а витоплення желатину різко зменшується. Бажаний ступінь м'якшення голини досягається за витрат води 100 - 200\% золеної маси та кількості витопленого желатину 8,9-12,1\%. Слід відзначити, що зменшення витрати води до 100\% сприяє підвищенню ступеня витоплення желатину і надає можливість одержати структурований напівфабрикат 3 комплексом підвищених фізико-механічних і санітарно-гігієнічних властивостей.

Таблиия 4. Ефективність м'якшення знезоленої голини

\begin{tabular}{|c|c|c|}
\hline $\begin{array}{c}\text { Витрата води, } \\
\text { \% маси голини }\end{array}$ & $\begin{array}{c}\text { Витоплення желатину, \% сухого } \\
\text { залишку м’якшеної голини }\end{array}$ & $\begin{array}{c}\text { Пром’якшеність голини за } \\
\text { органолептичною оцінкою }\end{array}$ \\
\hline 100 & 12,1 & хороша \\
200 & 8,9 & задовільна \\
300 & 7,7 & недостатня \\
400 & 7,4 & незадовільна \\
\hline
\end{tabular}

Дослідження пошарового витоплення желатину з голини після зоління протягом 3 діб за концентрації ензимного препарату 2,2 г/л і температури 35$37^{\circ} \mathrm{C}$ (табл. 5) показує, що витоплення желатину з сосочкового шару знезоленої голини в 3,6 раза перевищує цей показник для сітчастого шару дерми.

Таблиия 5. Пошарове витоплення желатину з м'якшеної голини панкреатином

\begin{tabular}{|c|c|c|}
\hline \multirow{2}{*}{ Напівфабрикат } & \multicolumn{2}{|c|}{ Витоплення желатину, \% сухого напівфабрикату, 3 шару } \\
\cline { 2 - 3 } & сосочкового & сітчастого \\
\hline знезолений & 16,9 & 4,7 \\
м'якшений 1 год & 93,6 & 34,8 \\
м'якшений 3 год & 99,5 & 36,1 \\
\hline
\end{tabular}


Як видно 3 табл. 5, після м'якшення голини протягом 1 год витоплення желатину суттєво зростає і за три години оброблення панкреатином цей показник для сосочкового шару дерми наближається до $100 \%$, тоді як для сітчастого шару досліджуваний ефект виражений у 2,7 раза слабше. Отже, після зоління голини протягом 5 діб майже весь колаген сосочкового шару дерми перетворюється у желатин, за винятком базальних мембран.

У процесі подальших досліджень у промислових умовах приватного AT «Чинбар» для м'якшення знезоленої голини був використаний ензимний препарат Chemizym BН за витрати $0,3 \%$ та води $100 \%$ маси золеного напівфабрикату (табл. 6). Як свідчать одержані результати, м'якшена голина порівняно зі знезоленою характеризується підвищеними показниками пористої структури, зокрема питомої поверхні, що досягає $22 \%$. Це можна пояснити ефективним звільненням структури колагену дерми від мукополісахаридів та інших неколагенових структурних компонентів унаслідок руйнування міжструктурних зв'язків з поліпептидними ланцюжками біополімеру, навіть таких міцних, як іонні та ковалентні.

Таблиця 6. Сорбційно-дифузійні властивості м'якшеного напівфабрикату

\begin{tabular}{|c|c|c|}
\hline \multirow{2}{*}{ Показник } & \multicolumn{2}{|c|}{ Напівфабрикат } \\
\cline { 2 - 3 } & знезолений & м'якшений \\
\hline Пористість, \% & 57,0 & 66,0 \\
Максимальна сорбція водяної пари, \% & 48,0 & 57,0 \\
Гігроскопічність, \% & 54,0 & 63,0 \\
Питома поверхня, ${ }^{2} / \Gamma$ & 112,0 & 137,0 \\
Капілярна волога при обводненні, \% & 89,0 & 106,0 \\
Паропроникність, мл/(см ${ }^{2} \cdot$ год), з боку & & 15,0 \\
бахтарми & 12,0 & 6,0 \\
лицьового & 3,5 & \\
Повітропроникність, мл/(см².год), з боку & & 910,0 \\
бахтарми & 690,0 & 690,0 \\
лицьового & 570,0 & \\
\hline
\end{tabular}

3 наведених даних видно, що процес м'якшення знезоленої голини супроводжується суттєвим підвищенням повітро- і паропроникності напівфабрикату. Слід зауважити, що дифузія парів води відбувається шляхом послідовного проходження процесів сорбції і десорбції молекул води на елементах структурованого біополімеру. Відмінність між процесами дифузії повітря і парів води з бахтарм'яного і лицьового боків пояснюється наявністю відкритих пор значного розміру з бахтарм'яного боку напівфабрикату, які утворюються при двоїнні золеного напівфабрикату. При цьому зростання пористості структури напівфабрикату після м'якшення супроводжується збільшенням гігроскопічності й сорбції водяного пару, що важливо для комфортної експлуатації шкіряних виробів.

Ефективність процесу м'якшення голини також виявляється в специфіці кінетики змін комплексу фізико-механічних показників (табл. 7). Зокрема, після одногодинного м'якшення знезоленого напівфабрикату міцність як структурованого напівфабрикату при розриванні, так і його лицьового шару 
підвищується порівняно зі знезоленим на $21 \%$, але збільшення тривалості м'якшення голини до трьох годин сприяє наближенню цього показника до значення знезоленого напівфабрикату, що вказує на ослаблення міжволоконних зв'язків дерми внаслідок тривалішої дії ензиму. Одночасно з цим відбувається підвищення деформаційних показників структурованого напівфабрикату. Цим же ефектом зумовлена висока залишкова деформація, що сприяє зменшенню витрат шкіряного матеріалу при формуванні виробів.

Таблиия 7. Фізико-механічні властивості структурованого напівфабрикату

\begin{tabular}{|c|c|c|c|c|}
\hline \multirow{2}{*}{ Показник } & \multicolumn{4}{|c|}{ Напівфабрикат } \\
\cline { 2 - 5 } & \multirow{2}{*}{ знезолений } & \multicolumn{3}{|c|}{ м’якшений, год } \\
\cline { 3 - 5 } & & 1 & 2 & 3 \\
\hline Межа міцності при розриванні, МПа & 12,0 & 14,5 & 13,7 & 12,4 \\
Поява тріщини лицьового шару, МПа & 10,2 & 14,5 & 13,7 & 12,4 \\
Видовження при напруженні 10 МПа, \% & 23,0 & 31,0 & 35,0 & 42,0 \\
Видовження при розриванні, \% & 36,0 & 47,0 & 52,0 & 64,0 \\
Залишкове видовження, \% & 6,0 & 11,0 & 14,0 & 23,0 \\
\hline
\end{tabular}

Отже, м'якшення знезоленої голини з використанням ензимного препарату Chemizym BН з витратою 0,3\% іiі золеної маси протягом однієї години забезпечує оптимальний комплекс експлуатаційних властивостей і підвищену еластичність лицьового шару шкіряного напівфабрикату.

\section{Висновки}

Досліджено біотехнологічні процеси в технології формування шкіри 3 шкіряної сировини 3 використанням бактерій Bacillus subtilis та ензимних препаратів панкреатину і Chemizym BН. Встановлено скорочення тривалості технологічного процесу відмочування шкіряної сировини вдвічі та зменшення на 20\% витрати екологічно шкідливих реагентів при іiі золінні. Для ефективного формування структури і властивостей поліфункціональних шкіряних матеріалів необхідно підтримувати оптимальне співвідношення між тривалістю процесів зоління і м'якшення залежно від технологічного режиму оброблення сировини.

Розроблена біотехнологія відмочування-зоління шкіряної сировини надає можливість об'єднати виконання послідовних процесів лужного оброблення колагенвмісної сировини в одностадійний технологічний цикл. Така технологія забезпечує формування еластичного шкіряного матеріалу з комплексом високих фізико-механічних і санітарно-гігієнічних властивостей.

Для виробництва еластичних шкір хромового дублення - взуттєвих, у тому числі для робочого і військового взуття, одягових і галантерейних можна вважати доцільним проведення процесів зневолошування-зоління 3 використанням ферментного препарату Chemizym BН при концентрації 0,3\% та витраті води $100 \%$ маси золеного напівфабрикату впродовж 12 год з подальшим одногодинним м'якшенням.

Показано, що розроблений процес зневолошування шкіряної сировини, завдяки використанню бактерій Bacillus subtilis може проводитись за відсутності екологічно шкідливих реагентів при скороченні тривалості процесу 
м'якшення на $30-33 \%$ порівняно 3 трудомісткою сульфідно-вапняною технологією, що передбачає зневолошування намазним способом.

Використання біохімічних реагентів у технологіях виробництва поліфункціональних еластичних матеріалів забезпечить ефективне використання хімічних реагентів і суттєве зменшення вмісту екологічно шкідливих речовин у стічних водах.

\section{Лiтература}

1. Urushadze Z. About a Real Conceptual Framework for Enzyme Catalysis. Bull. Georgian Natl. Acad. Sci. Vol. 173, No 2. 2006. P. 421-424.

2. Su Li. Ziran kexue ban / Su Li, Zhang Zhihong, Xiao Xianzhi, Wang Xiaomin // J. Wuhan Univ. Natur. Sci. Ed. 1996. V. 42. N 4. P. 516-518.

3. Шестакова И.С., Моисеева Л.В., Миронова Т.Ф. Ферменты в кожевенном и меховом производстве. Москва: Легпромбытиздат, 1990. $128 \mathrm{c}$.

4. Суховеркова А.М., Антипова Л.В., Косенко И.С., Василенко О.А. Современные методы получения обеззоленных шкурок кролика. Современные проблемы науки и образования. 2009. № 3, Ч. 2. С. $74-75$.

5. Širvaitytè, Justa. Bating of pelts after deliming with peracetic acid / Justa Širvaityte, Virgilijus Valeika, Kęstutis Beleška, Violeta Valeikienè. Proc. Estonian Acad. Sci. Chem. 2006. Vol. 55. P. $93-100$.

6. Altan Afsar, Cetinkaya Fatma Studies on the degreasing of skin by using enzyme in liming process. Indian Journal of Chemical Technology. 2008. Vol. 15. P. 507-510.

7. Единая технология обработки шкурок кроля / утв. И.Г. Гриценко. Москва: ЦНИИТЭИлегпром, 1990. С. 13, 29, 45.

8. Технология обработки меховых овчин / утв. А.А. Бирюков. Москва: ЦНИИТЭИлегпром, 1990. С. 85, 167, 169, 197. 